Nonprofits for Hire 



\section{Nonprofits for Hire}

The Welfare State in the Age of Contracting

Steven Rathgeb Smith

Michael Lipsky

Harvard University Press

Cambridge, Massachusetts

London, England 
Copyright $\odot 1993$ by the President and Fellows of Harvard College

All rights reserved

Printed in the United States of America

Third printing, 1998

Library of Congress Cataloging-in-Publication Data

Smith, Steven Rathgeb, 1951-

Nonprofits for hire : the welfare state in the age of contracting / Steven Rathgeb Smith and Michael Lipsky.

p. cm.

Includes index.

ISBN 0-674-62638-9 (cloth)

ISBN 0-674-62639-7 (pbk.)

1. Social service-United States-Contracting out. I. Lipsky, Michael. II. Title. HV95.S585 1993

361.6 - dic20 92-26625

CIP 


\section{For Penny}

and

to the memory of Julius and Helen Robinson McClain 
